\title{
カスパリー線の構造：細胞が編み上げた芸術作品
}

\author{
唐原一郎 \\ 富山大学理学部生物学科 \\ （テ930-8555＼cjkstart富山市五福3190）

\section{Structure of the Casparian strip: an artwork knitted by cells Ichirou Karahara}

\author{
Department of Biology, Faculty of Science, Toyama University \\ 3190 Gofuku, Toyama 930-8555, Japan
}

要旨 : カスパリー線は、その名の由来でもある19世紀のドイツの植物学者Robert Casparyによって存在が 世に知らされた。以来、根における物質輸送の要としての機能とその重要性については明らかにされてきた 一方、発達の仕組みについては余り調べられておらず今でもよくわかっていない。しかしその発達は植物生 理学の視点のみならず植物形態学の視点からも興味深く、特にその芸術的ともいえる網状構造は、植物形態 学を志す者にとって挑戦的でさえある。カスパリー線の形づくりについては、まだまとめるというほど十分 な知見が蓄積しているとは言えないが、ここでは、これまでの知見を整理しながら、その形が私たちに示す 課題を現代の視点で捉え直し、実験形態学的試みを含めて、それに対する様々な角度からの試みを紹介す る。

Summary: The structure of the Casparian strip was first described by the German botanist Robert Caspary in the 19th century. The function of the Casparian strip as an apoplastic barrier for solute transport is now fairly well understood. However, up to now the formation and the development of the Casparian strip is still an open question not only for plant physiologists but also for plant morphologists. Therefore, in the following I will try to rise some new questions and I will try to point out some new experimental approaches, which will be necessary in future in order to find answers to these questions concerning Casparian strip formation and development.

Key words: Casparian strip (band), endodermis, Pisum, lignin, suberin

1.はじめに : なぜカスパリー線か

水や溶質を適切に吸収・保持し地上部へ送ることは根の最も重要な機能である。それを保証するために、 全ての維管束植物の根の内皮には、隣り合う内皮細胞の間の細胞壁（transverse wall とradial longitudinal wall）の一部において、細胞をバンド状に取り囲むように疎水性物質が沈着し細胞膜が細胞壁 
に強く接着したカスパリー線

(Casparian strip または

Casparian band）という細胞間構 造が発達する。根の横断切片で見 るとカスパリー線はその断面がド ット状に見える（図 1 b）。この構 造はアポプラストにおける物質輸 送の局所的なバリアとして中心柱 内外でアポプラスト環境を隔て、 中心柱内に溶質や水を保持する役 割を果たしている（Clarkson and Robards 1975; Haas and

Carothers 1975; Peterson et al. 1981; Peterson et al. 1993)。力 スパリー線は内皮において普遍的 に形成される一方、多くの植物種 において、下皮にも形成される

(Peterson 1988; 森田と阿部 1999) てはこれまでよく調べられてきたが、発達の制御や分子構造については余り調べられていない。

カスパリー線は、細胞の一部分のみをバンド状に取り巻くように形成され、しかも内皮全体で完全につな がっていなければ、物質輸送のバリアとしての機能を果たさないはずである。なぜ細胞を取り巻く一部分に のみ疎水性物質が沈着するのか、どうしてそれが細胞という枠組みをこえてつながっているのかなど、その 形成の仕組みを細胞レベルで考えると、形態学上とても興味深い問題が浮かび上がる。ここではカスパリー 線について形態学の視点からこれまでの知見と問題点をまとめたい。

\section{2.カスパリー線とは何か : その機能}

まずカスパリー線の機能について簡単に触れる。最初に断るがこれは古典的な概念に基づいた教科書レべ ルでの説明（Taiz and Zeiger 1991; Mohr and Schopfer 1995）である。もし、より詳細な、すなわち力 スパリー線がどの程度溶質や水に対してのバリアとして働いているかについての説明を試みると、溶質と水 のそれぞれの成分についてはどうか、あるいは、アポプラスト経路とシンプラストおよび膜を介した経路の 寄与がどの程度かといったことがまだはっきりしていないため（Boyer 1985; Passioura 1988; 加藤 1991; Zimmerman and Steudle 1998）、話は複雑となる。そのため教科書レべルでは古典的な概念にとどまら ざるをえないという状況であると考えられ、従ってここでも古典的な概念にとどめたい。しかしここで指摘 しておきたいことは、かかる話が複雑にならざるをえない原因の一つとして、これらの解析にカスパリー 線、内皮、外皮の発達についてのきちんとした形態学的解析が伴っていないことがあると筆者は考える。物 質輸送に関して生理学的手法に形態学的手法を組み合わせた解析（Melchior and Steudle 1993; Peterson et al. 1993; Zimmerman and Steudle 1998）は評価できるし最近では化学分析も組み合わせ始められてい るが、残念なのは、形態学的な部分についてはまだ定性的な域を脱していないことである。形態学的解析と はいえ、今後はより厳密かつ定量的な解析が必要である。

さて根の表面（根毛など）から取り込まれた溶質や水の放射方向の動きを考える。取り込まれた溶質や水 
は地上部へ輸送されるために中心柱内部の道管に入る。 しかし道管は死細胞なので、道管に入るということは細 胞外すなわちアポプラストへ出ることを意味する。アポ プラストは溶質や水を通しやすいため、溶質や水の動き を阻止するような構造がアポプラストになければ、せっ かく取り込んだ溶質や水がアポプラスト経由で外へ漏れ 出す可能性がある。またアポプラスト経路には取り込む ものを選択する仕組みがないため、逆に不要または有害

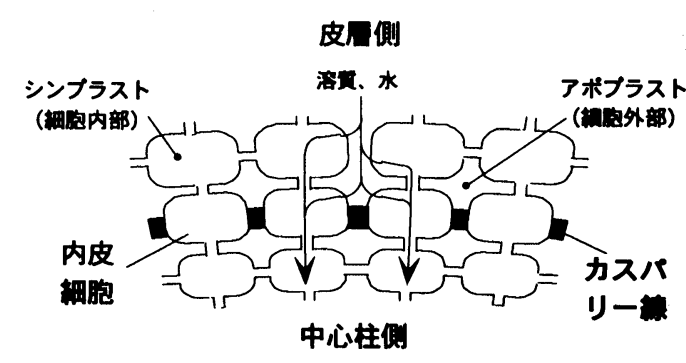

図 2 根の内皮近くにおける溶質や水の放射方 向の流れを示す模式図。（唐原 1995 より改変） な物質をアポプラスト経由で道管に取り込む可能性もあ る。隣り合った皮細胞の間でアポプラストをシールするカスパリー線が発達してこのようなことを防いで いる。これにより、溶質は内皮に到達するまでに細胞膜による選択的な取り込みを受けてアポプラストから シンプラストへ入る。水は溶質の移動に伴ってシンプラストに入る。そしてシンプラストに入った溶質や水 だけが中心柱に入り道管に到達する（図 2）。根の軸に沿って見た場合、カスパリー線が形成されていない 根端付近や、カスパリー線が形成された後でより内皮の細胞壁の修飾が進んだ部位においては、一般的に溶 質や水の吸収は低下していると考えられている。

\section{3. 微視的な構造 : 微細構造および分子構造}

カスパリー線はバリアとしての機能を保証するため、どのような構造をとっているのか。まず微視的な構 造の観点から見る。カスパリ一線の発達を細胞レベルで調べるためには、発達の指標となる分子マーカーが 必要である。そしてカスパリー線の機能を明らかにするためには、構造を分子レベルで明らかにすることは 重要である。またバリアとしての機能から考えると、環境要因によりカスパリー線の分子構造が変化するか についても興味深い。そのような要請から細胞壁分解酳素を用いてカスパリ一線の単離が行われた

（Karahara and Shibaoka 1992; Schreiber et al. 1994）。その後カスパリー線に限らず様々な発達段階 の内皮や外皮の単離も行われており（Zeier et al. 1999a; Zeier et al. 1999b）、それらについては他の総説 (Schreiber et al. 1999) にゆずり、ここでは内皮のカスパリー線についてのみ述べる。しかし、内皮のカ スパリー線が形成されている部分は、根がさかんに水や溶質を吸収している部分と重なっている可能性が高 く、しかもこの部分における溶質や水の放射方向の移動の唯一のバリアが内皮カスパリー線であると考えら れるため、その成分こそ根の水透過性に重要であるという可能性は高いと思われる。

\section{1 ）細胞壁部分の修飾}

カスパリー線の形態についての最初の記述（Caspary 1858）以来、その化学組成を探る試みは主に光学 顕微鏡を用いて組織化学的な方法により行われ、スベリンやリグニンの存在が示唆されてきた (Brundrett et al. 1988）。その証明は1990年代になって単離法の開発とガスクロマトグラフィーと質量分析を組み合 わせることで行われた（Schreiber et al. 1996; Zeier and Schreiber 1997; Zeier and Schreiber 1998; Zeier et al. 1999a）。これまで吸収機能を持つ根としては 2 種で調べられている。アポプラスト輸送バリ アとして重要な成分は疎水性物質としての不飽和脂肪酸を含むスベリンであるが、その含量はエンドウの根 のカスパリー線の場合乾燥重量の2.5\%であり、これは表皮の約 2 倍の值であった（Zeier et al. 1999a）。 ちなみにClivia miniata の場合は1.2\%である（Zeier and Schreiber 1997）。リグニンは、エンドウの場合 乾燥重量の2.7\%であり、これは道管の約半分の值であった（Zeier et al. 1999a）。ちなみにClivia miniata の場合は5.2\%である（Zeier and Schreiber 1997）。また少なくともエンドウの根のカスパリー線には、 ワックスやクチンが存在するという明確な証拠は得られていない。スベリンはワックスがともに沈着しない 
場合スベリン単独だけではバリアとしての機能は高くない（Shoenherr 1982）という示唆もあり、スベリ ン含量だけでバリアとしての効果の大きさを議論することはできない。今後は化学分析・生理学的解析・形 態学的解析を組み合わせた三位一体の研究が必要である。ところでスベリンについてはカスパリー線の機能 からその必要性は明らかであるが、リグニンを含むのはなぜか。構造を強固に保つためという理由が考えら れるが、これについては後述する。また別の可能性の一つに、微生物の感染を防ぐためという考え方がある (Schreiber et al. 1999)。カスパリー線は一次壁の一部に二次壁成分が沈着して起こるわけであるが、一 次壁の構成を変えないでそのすき間に二次壁成分が沈着しているのかどうかはわからない。一次壁の成分の 分解も同時に起こっている可能性が考えられる。

2 ）タンパク質成分について

Monstera deliciosa とClivia miniata のカスパリー線はアミノ酸を含むことがわかっている (Schreiber et al. 1999）。また私達はエンドウの根から単離したカスパリー線よりタンパク質を抽出することでいくつ かのカスパリー線特異的と考えられるポリペプチドの候補を得ている。その中には部分アミノ酸配列を決定 しているものもあり、今後CDNA を単離する予定である。

\section{3 ）細胞膜と細胞壁の接着}

カスパリー線においては細胞膜が細胞壁と強く接着していることが知られている。この接着が溶質のバリ アとしての機能に重要であることは、電子密度の高いアポプラストトレーサーを用いて微細構造を観察した 実験により「直観」できる。根から $\mathrm{La}^{3+}$ 取り込ませてカスパリー線を観察した場合、 $\mathrm{La}^{3+}$ は主に細胞膜と 紐胞壁との間に分布したが、内皮細胞の放射壁においてはカスパリ一線より皮層側にしか観察されなかった

（Nagahashi 1974）。このことは、カスパリー線の細胞壁部分に疎水性物質が沈着して疎水性が高くなっ ていたとしても、細胞膜と細胞壁の接着が弱く不安定なものであれば、細胞膜と細胞壁の間から物質が侵入 する可能性があるが、この接着が強いことでそれを防いでいるということを示唆している。この接着のた め、内皮細胞が原形質分離した場合には、カスパリー線の部 分でのみ細胞膜は細胞壁から離れないため、あたかもカスパ リー線の部分で細胞質がつながっているかのようにバンド状

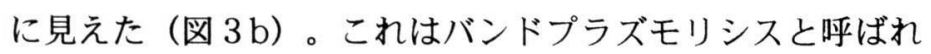
古くから知られている現象である（Bryant 1934）。この接 着は不可逆的であると考えられ、内皮細胞がカスパリー線の 内側（細胞質側）にさらなる細胞壁の修飾を発達させたと き、カスパリー線の部分の細胞膜は細胞壁から剥がれるので はなく細胞壁に付着したまま残り、その上から新たな細胞膜 が形成されていた（Bonnet1969; Scott and Peterson 1978; Karahara 1998）。このことから、この接着の強さは少なく とも膜の構造を保つための膜脂質分子どうしの結合の力より も強いのだろうと考えられている。この接着をした細胞膜 を、細胞膜の構造を保ったまま細胞壁から引き離せるような 処理は今の所見つかっていない。内皮細胞の細胞膜タンパク 質は皮層側と中心柱側で異なるように極性を持って分布して いると思われ、これが混ざり合わないようにするためにカス パリー線は膜上のフェンスとしての役割も果たしている可能 性が考えられる。

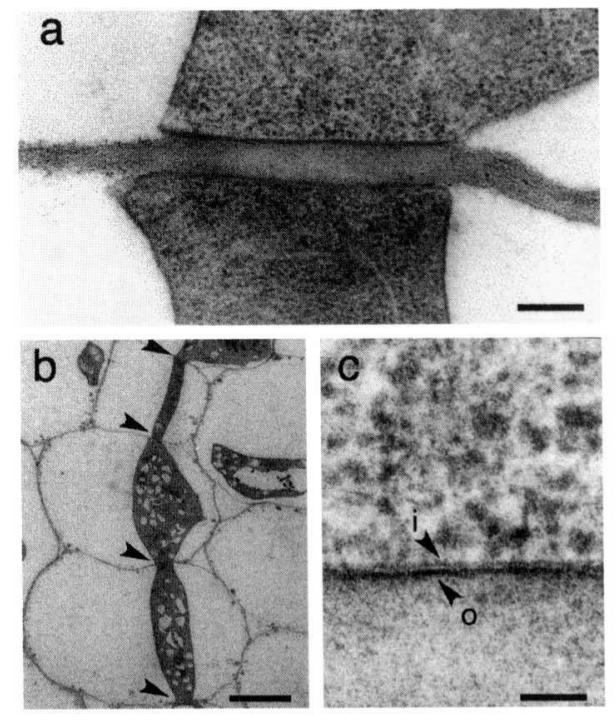

図 3 エンドウの根のカスパリー線の電子顥 微鏡写真。(a) 原形質分離した 2 つの内皮細 胞の間の細胞壁の一部。細胞膜はカスパリー 線の部分でのみ細胞壁に接着している。bar $=0.2 \mu \mathrm{m}$ 。(b) 原形質分離した内皮細胞。矢 尻はカスパリー線の位置。bar=5 $\mu \mathrm{m}$ 。(c) カスパリー線の部分の細胞膜。細胞膜の外側 の層(o)が内側の層(i)に比べて電子密度が高 く見える。bar $=0.05 \mu \mathrm{m}$ 。 (Karahara and Shibaoka 1992より改変) 
この特殊な接着の分子機構を示唆する知見には以下のようなものがある。カスパリー線の微細構造を観察 すると、切片が細胞膜に対してうまく垂直に切れた場合、細胞膜の脂質二重層がはっきり見える。化学固定 の場合、通常細胞膜はたるんで見え脂質二重層がはっきり見えることは少ないが、カスパリー線においては 例外的に細胞壁に治って 2 層が直線的にはっきり見える。このことから、この特殊な接着は、スベリン化さ れた疎水性の細胞壁成分と、細胞膜の脂質または膜夕ンパク質の疎水性の部分との強固な結合によるもので はないかという可能性が示唆されている（Bonnet 1967）。

さらにこの細胞膜部分を電子顕微鏡レベルで詳細に見た場合、その見え方は植物種によって違うが、例え ばエンドウの根の場合、内皮のカスパリー線以外の細胞膜の部分では、2 層の厚さや電子密度が同じに見え るのに対し、カスパリー線の部分においてのみ、 2 層の厚さが異なって見え、通常の厚さである細胞質に面 する側の層に比べて細胞壁に面する側の層の方はより厚く電子密度が高く見えた。このことから、この接着 に関わる分子は細胞壁に面する側の層に存在するのではないかと考えられる（図 $3 \mathrm{c} ）$ 。同様の観察が Ledbetter（1967）によって報告されている（植物種は不明）。またトウモロコシの根の内皮カスパリー線 においては、何らかの膜内粒子らしきものが規則的に立んだかのようなパタンに見えていた (Zeier et al. 1999)。

エンドウの根から単離したカスパリー線には、細胞膜の細胞壁側の層が付着して残っていた。そこでこれ が消えるような洗浄条件を探した。 $8 \mathrm{M}$ 尿素溶液などのカオトロピックイオンで洗浄してもはずれなかった が、トライトンX-100で洗浄したところ、細胞壁に面する側の層は外れた。従って、接着に関わる分子は膜 表在性タンパク質ではなく、膜内在性のタンパク質か脂質のようなものではないかと考えられる

(Karahara and Shibaoka 1992) 。ただし、単離カスパリー線をトリプシンで処理してもこの層の見え方 は変わらなかった（未発表データ）。

\section{4. 巨視的な構造 : 立体構造}

カスパリー線を単離することにより、カスパリー線が全ての細胞でつながっていることが直接的に示され た（図 4)。興味深いのは、エンドウの根から単離されたカスパリー線は伸びているのに対し、内皮を含む 接線切片を切った場合つまり組織の中では波打って見えることである（図 1c）（Esau 1964; Peirson and Dumbroff 1969; Karahara and Shibaoka 1992）。一方、単離された場合でも、Clivia miniataの根の場 合（Schreiber et al. 1994）やエンドウ茎の場合はカスパリー線は波打っている（未発表データ）。これら の場合は、カスパリー線に接する部分の内皮細胞壁が二次壁成分により修飾されていて、その部分が細胞壁 分解酵素によって分解されずに付着したまま残っていたためであ ると考えられる。

なぜカスパリー線は波打っているのか。以下は推測である。カ スパリー線にはリグニンが含まれるため、ある程度強固な構造に なっていると考えられる。従って、カスパリー線が形成された細 胞ではカスパリー線はたがになってしまい、もしカスパリー線に ゆとりがなければ長軸方向に伸長することは全くできないか、無 理に伸長した場合カスパリー線が切断されてしまう可能性が考え られる。波打つことで細胞の一時的な体積変化に備えて余裕を持 たせているのではないだろうか。

植物体が盛んに蒸散を行っている場合、蒸散による水の損失が 供給よりも増大するため、強力な陰圧が道管内にかかると言われ

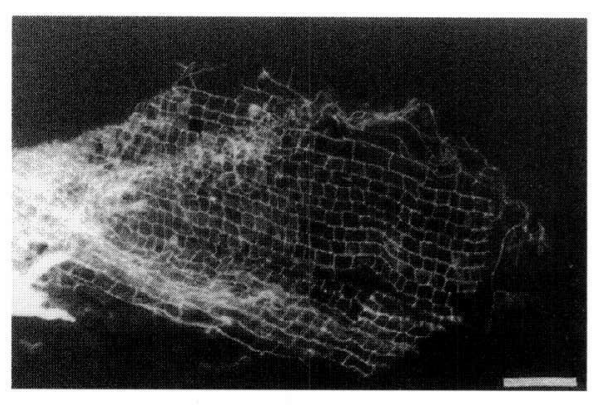

図 4 カスパリー線の立体構造。エンドウ の根から単離したカスパリー"網"。カスパ リー線は全ての内皮細胞で厳密につながっ ている。虽光像。bar $=100 \mu \mathrm{m}$ 。（唐原 1995より改変） 
ている（Mohr and Schopfer 1995）。また逆に、蒸散の起こりにくい 条件下においては、水やイオンの長距離輸送を行うために道管内に陽圧 がかかり、それによって出液が起こる。これらの場合、その圧力はアポ プラスト内の水を伝わっていくと考えられている。カスパリー線がこの ような圧力に耐えながらアポプラストバリアとしての役割を果たすため には、機械的にもかなり強固な構造である必要があると考えられる。力 スパリー線はリグニンが道管における含量（乾燥重量に対するパーセン テージ）の值の約 $1 / 2$ も含まれることも、細胞膜が細胞壁に不可逆的に 接着していることもこのためではないかと思われる。

\section{5. 細胞レベルでの形成の仕組み}

次にカスパリー線の成分がカスパリー線の位置に局在していく仕組み

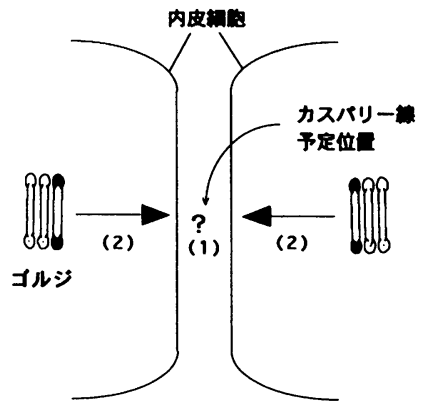

図 5 カスパリー線の形成につ いての作業仮説を示す模式図。 (1) カスパリー線の予定位置に 何らかの情報が蓄種し、(2) そ こへめがけてカスパリー線の成 分が何らかの形で㻌送される。 など、細胞レベルでの形成の仕組みを考える。まずカスパリー線の形成 の仕組みについて、次のような作業仮説を考えた。内皮細胞の分化過程のある段階で、カスパリー線の予定 位置に何らかの情報が局在し、そこへめがけてカスパリー線の成分が何らかの形で輸送されるというもので ある（図 5) 。この考え方では、その情報が局在する仕組みについてまた同じ仮説が必要であり、ニワトリ と卵の問題をはらむが、現時点で私たちがカスパリ一線の形成を知るのは二次壁が形成してからでありほと んぞ最終段階であるため、少しでも形成過程を上流へさかのほることが重要である。

\section{1）分泌輸送の関与}

二次壁成分が何らかの形で予定位置へ輸送されることは確かである。リグニンの前駆体は細胞質で合成さ れ、細胞壁へそのままあるいは分泌輸送経路を経て放出され細胞壁中でポリマーへと重合されると考えられ ているが (Mohr and Schopfer 1995; Lewis and Yamamoto 1990; Campbell and Sederoff 1996)、こ のことと、なぜリグニン化が局所的に起こるのかという問題のギャップは大きい。またスベリンの成分がど のように輸送されるのかはよくわかっていない。

まずカスパリー線形成中の内皮細胞の微細構造を調べた。カスパリー線の発達は内皮全周で常に均一にお こっているわけではない。形成中のカスパリー線の微細構造を観察すると、あたかも分泌小胞がカスパリー 線の所で細胞膜で融合してエキソサイトーシスされているかのような様子が観察されることがある（Scott and Peterson 1978; 唐原 1995）。カスパリー線の構成成分に関する知見がまだそしいため、分泌輸送され る分子については現時点でははっきりしないが、二次壁成分をはじめ何らかの構成成分の輸送に分泌輸送が 関わっている可能性は高いと考えられるため、カスパリー線形成の細胞内過程を明らかにする第一歩とし

て、阻害剤を用いてまず分泌輸送が関わっているかどうかを調べた。

阻害哓投与や外科的処理など、細胞生物学的・生理学的実験によって細胞レベルでの形成を調べるために は、根よりも発達段階を揃えやすく扱いが容易な茎を用いると有利である。エンドウでは暗所で育てた場 合、黄化上胚軸にもカスパリー線が形成されることが知られている (Priestley 1926; Karahara and Shibaoka 1994）。そこでエンドウ茎を用いた実験系を確立した。暗所で 7 日間育てた黄化エンドウ上胚軸 でカスパリー線が形成されるのはフックの屈曲点の約 $37 \mathrm{~mm}$ 下位置であることから、フックの屈曲点の 下約 $37 \mathrm{~mm}$ より上の部分はカスパリー線の形成過程を進行中の全ての分化段階の内皮細胞を含むことにな る。そこでこの芽生えの屈曲点の下 $37 \mathrm{~mm}$ の位置に糸を通し、その糸を介してゴルジの機能の特異的な阻

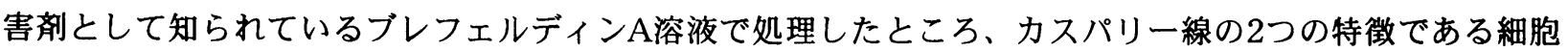
壁の修飾及び細胞膜と細胞壁の接着は阻害され、両者の形成に関与する成分の輸送にゴルジを経由した分泌 
輸送経路が関与していることが示唆された（Karahara and Shibaoka 1998）。

カスパリー線の特徵である細胞壁と細胞膜の特殊な接着および細胞壁の修飾ではごちらが先におこるの か。もし後述のようにカスパリー線を構成する二次壁成分が分泌輸送されるならば、先に細胞壁と細胞膜の 特殊な接着がおこってしまうと、二次壁成分を運ぶ小胞は細胞膜と融合できないので不都合であると推測さ れる。エンドウ黄化上胚軸において細胞壁と細胞膜の特殊な接着と細胞壁の修飾ではどちらがより先端近く まで見られるかを調べたところ、細胞壁の修飾がわずかに先行しており、カスパリー線が発達している部分 で細胞壁の修飾がおこっているのに特殊な接着が見られない部分が存在した（Karahara and Shibaoka 1998）、この結果から細胞壁の修飾の方が特殊な接着の形成に先だっておこると考えられる。カスパリー 線は機能のアナロジーから植物のタイト・ジャンクションと呼ばれることがある。タイト・ジャンクション を持つ動物上皮細胞は極性輸送の研究に使われてきたが、ここで言う極性輸送とは、いわばタイト・ジャン クションの構成成分がアセンブリされてタイト・ジャンクションの位置に局在するためのものであり、一般 的な極性輸送の仕組みと比べるとより厳密な制御が必要と思われる。植物の極性輸送の仕組みについては突 然変異体を用いた研究から近年急速に明らかになりつつあり（Steinmann et al. 1999）、こういった方面 からの研究に期待が持たれる。

分泌輸送阻害剤の実験において、副次的に興味哚いことがわかってきた。カスパリー線形成が阻害された 内皮細胞と阻害されなかった内皮細胞との間で、細胞壁の修飾も細胞膜の接着も片側のみできた、半分の力 スパリー線が観察された（図6）。また両側の細胞でカスパリー線が形成された場合でも、両側で幅がちぐ はぐになったカスパリー線なども見られた。これらのことは、カスパリー線は隣り合う内皮細胞が半分ずつ 作っていること、つまりカスパリー線は個々の内皮細胞が作っていることを明確に示唆している。にもかか わらず、全ての内皮細胞で厳密につながっている（図4）のはどういうことだろうか。人間社会のインター ネットのように、細胞社会にも inter "cellular" net なるものがあって、情報が細胞間をかけめぐっている のだろうか?

2 ) カスパリー線の形成位置や幅についての問題

カスパリー線の形成位置や幅（放射壁中で放射方向に占める距離）は、内皮の放射壁の中でにおいてどの ように決まっているのだろうか。形成位置はランダムに見られるとか種によって違っているとかいうのでは なく、一般的に内側接線壁に近い側に形成される（Esau 1965）と言われていることから、種を越えた何ら かの共通な仕組みが存在すると思われる。これまでにカスパリー 線の形成位置に言及した仕事として、Van Fleet (1942) のも のがある。彼は幾つかの単子葉植物を用いてスベリン化に関わる と考えられるオキシダーゼ活性の局在を組織化学的に調べ、その 活性をカスパリー線形成の指標として見た。それによると、

Smilax glaucaの根の場合、内皮におけるオキシダーゼ活性の局 在は内皮と内鞘の境界の細胞間隙から始まり、最終的にはそこか ら放射壁の中央部方向に移動したが、この移動の原因は内皮細胞 が放射方向に拡大したためであると彼は考えた。この考えに対し て、Haas ら(1975)はトウモロコシの根の内皮カスパリー線の微 細構造の観察結果から、カスパリー線の位置は発達を通じて移動 することなく最初から厳密に決まっていると考え、Van Fleet の 観察は新鮮な試料を用いたため、固定されていない前駆体の動き を見ていたのだろうと考察している。カスパリー線におけるスベ

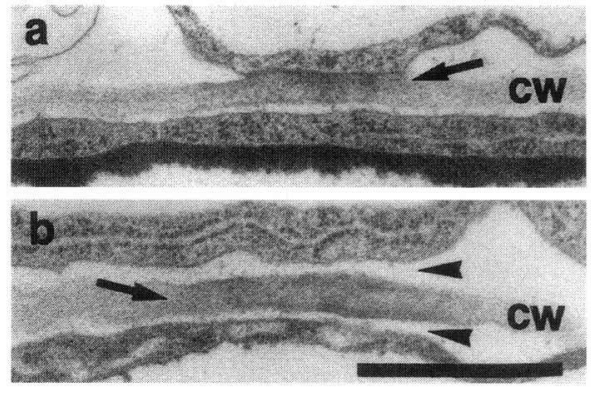

図 6 BFA処理して形成が異常になった エンドウの黄化上胚軸のカスパリー線。 細胞壁の修飾を見るためマンガン染色も 行つている。CW: cell wall。(a) 半分の カスパリー線。カスパリー線が上側の細 胞でしか形成されていない(矢印)。(b) 細胞壁の修飾は起こっている（矢印） が、細胞膜の接着はおこっていない（矢

尻)。bar $=1 \mu \mathrm{m}$ 。 (Karahara and Shibaoka 1998) 
リン化にオキシダーゼが関わったとしても、Van Fleet の見たオキシダーゼ活性がカスパリー線形成のみに 関与している確証はなく、また技術的な問題もあることは確かである。

一方、私たちは図 5 に示すようにカスパリー線の予定位置に輸送の目標となるような何らかの情報が存在 するのではないかという作業仮説を立て、まずそのような情報の存在の検証を試みた。上記の作業仮説に基 づくと、カスパリー線が形成する前に、既にカスパリー線形成の位置情報が蓄積した後に細胞が拡大したな ら、その後形成されたカスパリー線は細胞壁の拡大に応じて拡大すると考えられる。そこでエンドウの茎に 針を貫通させることで、カスパリー線が形成される前の内皮細胞を人為的に放射方向に拡大させた。その結 果、拡大した内皮細胞においては、放射壁の拡大とともに、カスパリ一線の幅も有意に拡大していることが わかった（Yokoyama and Karahara 2001）。このとき、細胞の拡大はカスパリー線の形成に先行してお り、またいったん形成されたカスパリー線は拡大しなかった。これらの結果は、カスパリ一線の予定位置 に、カスパリー線の位置と幅を決める何らかの位置情報が蓄積している可能性を示唆している。屈曲点から $4 \mathrm{~mm}$ 下の位置で処理を行った場合でもカスパリー線の幅の拡大が起こったことから、もしこの位置情報が 存在すると仮定するなら、この位置情報の蓄積は屈曲点から $4 \mathrm{~mm}$ 下の位置で既に起こっていると考えられ る。

また無処理でカスパリー線を形成した内皮細胞でカスパリー線の幅と放射壁の幅の関係を調べたところ、 両者の間には有意な相関が見られた。このことから、内皮細胞の発達段階において非常に早い時期には放射 壁の幅にばらつきがない時期があり、その時既にこの位置情報は蓄積されており、その後細胞の拡大が起こ つて放射壁の幅にばらつきが起こり、その後形成されたカスパリー線の幅に放射壁の幅に応じたばらつきが 生じるのだろうと推測される。エンドウの茎の横断切片を観察すると、希に、内皮細胞のカスパリー線とは 別に、内皮の隣りの細胞層にもカスパリー線が形成されていることがある（図 7 ）。位置情報についての仮 説に基づいてこの現象の原因を推測すると次のようになる。通常は内皮の前駆細胞が最後の並層分裂を行っ て内皮細胞が分化した後で位置情報が蓄積するが、この部分においては位置情報を蓄積した後で並層分裂を 行い、かつ細胞分裂面が蓄積した位置情報にかかったために、カスパリー線が両側の細胞にまたがってしま ったという可能性である。

カスパリー線の幅については、トウモロコシの根において、内皮細胞の発達段階を通じてカスパリー線の 幅が增大することが示唆されている（Barnabas and Peterson 1992）。幅の大きさの問題については、バ リアとしての機能に結びついている可能性があり、環境要因や位置情報との関連が考えられるため興味深 く、筆者の所でも研究を進めている。

\section{6.おわりに}

カスパリー線の形態に重点を置いたレビューとしては本レビ ユーが初めてのものになる。生理学的観点からのカスパリー線 の発達に関する研究については今回は余り触れなかったが、も う少し研究が進めば別の機会にまとめたい。内皮や外皮は物質 輸送の要として外部の環境変化から根の内部環境を守るという 役割を果たしている。茎の内皮の場合は重力屈性において重要 な役割を果たしている（Sack 1991; Fukaki et al. 1998;

Fujihara et al. 2000）。エンドウの茎においてはカスパリー線 形成が光により制御されている（Priestley 1926; Karahara and Shibaoka 1994; 高屋 2000）。また外皮の発達は様々な環

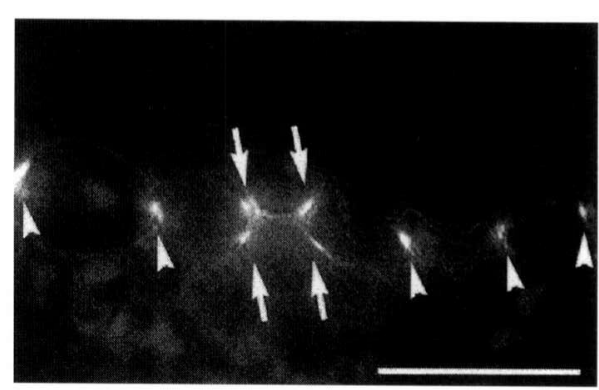

図 7 部分的に二層の細胞で形成されたカ スパリー線 (矢印)。エンドウの黄化上胚 軸横断切片の内皮周辺の蛍光像。矢尻は通 常のカスパリー線。bar=50 $\mu \mathrm{m}$ 。（横山 2000 より改変) 
境に制御されていることも知られている（Enstone and Peterson 1998; 森田 2000）。内皮や外皮の機能 の重要性から考えると、このように外部の環境変化に敏感にその発達が制御れていて当然であるとも考えら れる。内部組織の環境応答の仕組みは外部形態のそれに比べるとまだよく解明されているとはいえない。私 たちは、カスパリー線の発達を通じて、植物が環境ストレス等の外的要因に応答して内部組織の発達を制御 する仕組み、その制御における植物ホルモンなどの関わり、組織形成における細胞間の相互作用とそれによ る細胞内過程の制御、などについて腰を据えて明らかにしていきたいと考えている。

\section{謝辞}

奖励賞を授賞および本稿執筆の機会を与えて頂いた日本植物形態学会の皆様、本研究の過程でご指導を頂 いた元大阪大学理学部の柴岡弘郎博士、お世話になった大阪大学理学部細胞生理学講座および富山大学理学 部生物学科の皆様にこの場をお借りして厚く御礼を申し上げます。なお本総説には、日本学術振興会特別研 究員制度、笹川科学研究助成、富山大学教育改善推進費、文部省科学研究費補助金（No. 11740454）によ り推進された研究が含まれます。

文献

Barnabas, A. D., Peterson, C. A. (1992) Development of Casparian bands and suberin lamellae in the endodermis of onion roots. Can. J. Bot. 70: 2233-2237

Bonnett, H. T. J. (1968) The root endodermis: fine structure and function. J. Cell Biol. 37: 199-205

Bonnett, H. T. J. (1969) Cortical cell death during lateral root formation. J. Cell Biol. 40: 144-159

Boyer, J. S. (1985) Water transport. Ann. Rev. Plant Physiol. 36: 473-516

Brundrett, M. C., Enstone, D. E., Peterson, C. A. (1988) A berberine-aniline blue fluorescent staining procedure for suberin, lignin, and callose in plant tissue. Protoplasma 146: 133-142

Bryant, A. E. (1934) A demonstration of the connection of the protoplasts of the endodermal cells with the Casparian strips in the roots of barley. New Phytol. 33: 231

Caspary, R. (1858) Die Hydrileen. Jahrbuecher fuer wissenschaftliche Botanik 4; 101-123

Clarkson, D. T., Robards, A. W. (1975) The endodermis, its structural development and physiological role. In: Torrey, J. G., Clarkson, D. T. (eds) The development and function of roots. Academic Press, London, pp 415-436

Campbell, M. M., Sederoff, R. R. (1996) Variation in lignin content and composition. Plant Physiol. 110: $3-13$

Enstone, D. E., Peterson, C. A. (1998) Effects of exposure to humid air on epidermal viability and suberin deposition in maize (Zea mays L.) roots. Plant Cell Environ. 21: 837-844

Esau, K. (1965) Plant Anatomy. 2nd ed., Wiley, New York

Fujihara, K., Kurata, T., Watahiki, M. K., Karahara, I., Yamamoto, T. Y. (2000) An agravitropic mutant of Arabidopsis, endodermal-amyloplast less 1, that lacks amyloplasts in hypocotyl endodermal cell layer. Plant Cell Physiol. 41: 1193-1199

Fukaki, H., Wysocka-Diller, J., Kato, T., Fujisawa, H., Benfey, P.N., Tasaka, M. (1998) Genetic evidence that the endodermis is essential for gravitropism in Arabidopsis thaliana. Plant J. 14: 425-430

Haas, D. L., Carothers, Z. B. (1975) Some ultrastructural observations of endodermal cell development in Zea mays roots. Am. J. Bot. 62: 336-348

加藤潔 (1991) 多細胞植物の水輸送 物質の輸送と貯蔵, 茅野充男編, 朝倉書店, 東京, pp39-48

Karahara, I., Shibaoka, H. (1992) Isolation of Casparian strips from pea roots. Plant Cell Physiol. 33: 
$555-561$

唐原一郎 (1995) カスパリー線：植物のタイトジャンクション,化学と生物 33: 246-251

Karahara, I., Shibaoka, H. (1994) The Casparian strip in pea epicotyls: effects of light on its development. Planta 192: 269-275

Karahara, I. (1998) Structure of the Casparian strip in a plant root. Jap. J. Crop Sci. 67 (Extra issue 1): $284-285$

Karahara, I., Shibaoka, H. (1998) Effects of Brefeldin A on the development of the Casparian strip in pea epicotyls. Protoplasma 203: 58-64

Ledbetter, M. C. (1967) The Casparian strip: a site of a functional tight junction in plant roots. J. Cell Biol. 35: 79A

Lewis, N. G. and Yamamoto, E. (1990) Lignin: occurrence, biogenesis and biodegradation. Ann. Rev. Plant Physiol. Plant Mol. Biol. 41: 455-496

Mohr, H., Schopfer, P. (1995) Plant Physiology, Springer, Berlin

森田茂紀, 阿部淳（1999）植物の根に関する研究の課題, 日本作物学会紀事, 68: 453-462

森田茂紀（2000）根の発育学, 東京大学出版会, 東京

Nagahashi, G., Thomson, W. W., Leonard, R. T. (1974) The Casparian strip as a barrier to the movement of lanthanum in corn roots. Science 183: 670-671

Passioura, J. B. (1988) Water transport in and to roots. Ann. Rev. Plant Physiol. Plant Mol. Biol. 39: 245-265

Peirson, D. R., Dumbroff, E. B. (1969) Demonstration of a complete Casparian strip in Avena and Ipomoea by fluorescent staining technique. Can J. Bot. 47: 1869-1871

Peterson, C. A. (1988) Exodermal Casparian bands: their significance for ion uptake by roots. Physiol. Plant. 72: 204-208

Peterson, C. A., Emanuel, M. E., Humphreys, G. B. (1981) Pathway of movement of apoplastic fluorescent dye tracers through the endodermis at the site of secondary root formation in corn (Zea mays) and broad bean (Vicia faba). Can. J. Bot. 59: 618-625

Peterson, C. A., Murrmann, M., Steudl,e E. (1993) Location of the major barriers to water and ion movement in young roots of Zea mays L. Planta 190: 127-136

Priestley, J. H. (1926) Light and growth. II. On the anatomy of etiolated plants. New Phytol. 25: $145-170$

Sack, F. D. (1991) Plant gravity sensing. Int. Rev. Cytol. 127: 193-252

Shoenherr, J. (1982) Resistance of plant surfaces to water loss: transport properties of cutin, suberin and associated lipids. In: Lange, O. L., Nobel, P. S., Osmond, C. B., Ziegler, H. (eds) Encyclopedia of plant physiology, New series, Vol. 12B. Springer, Berlin, pp153-179

Schreiber, L., Breiner, H. W., Riederer, M., Dueggelin, M. (1994) The Casparian strip of Clivia miniata Reg. roots: isolation, fine structure and chemical nature. Bot. Act. 107: 353-361

Schreiber, L., Hartmann, K., Skrabs, M., Zeier, J. (1999) Apoplastic barriers in roots: composition of endodermal and hypodermal cell walls. J. Exp. Bot. 50: 1267-1280

Scott, M. G., Peterson, R. L. (1979) The root endodermis in Ranunculus acris. I. Structure and ontogeny. Can. J. Bot. 57: 1040-1062

Steinmann, T., Geldner, L., Grebe, M., Mangold, S., Jackson, C., Paris, S., Gaelweiler, L., Palme, K., Juergens, G. (1999) Coordinated polar localization of auxin efflux carrier PIN1 by GNOM ARF GEF. Science 286: 316-318

高屋恵里子 (2000) エンドウ上胚軸カスパリー線の発達に対する光の影響, 富山大学大学院理工学研究科 修士論文 
Taiz, L., Zeiger, E. (1991) Plant Physiology. Benjamin/Cummings, Redwood

Van Fleet, D. S. (1942) The development and distribution of the endodermis and an associated oxidase system in monocotyledonous plants. Am. J. Bot. 29: 1-15

横山正樹 (2000) カスパリー線の形成位置の指標となる情報および分子, 富山大学大学院理工学研究科 修士論文

Yokoyama, M., Karahara, I. (2001) Radial widening of the Casparian strip follows induced radial expansion of endodermal cells. Planta (in press)

Zeier, J., Goll, A., Yokoyama, M., Karahara, I., Schreiber, L. (1999a) Structure and chemical composition of endodermal and rhizodermal/hypodermal walls of several species. Plant Cell Environ. 22: 271-279

Zeier, J., Ruel, K., Ryser, U., Schreiber, L. (1999b) Chemical analysis and immunolocalisation of lignin and suberin in endodermal and hypodermal/rhizodermal cell walls of developing maize (Zea mays L.) primary roots. Planta 209: 1-12

Zimmerman, H. M., Steudle, E. (1998) Apoplastic transport across young maize roots: effect of the exodermis. Planta 206: 7-19 